\title{
Terrorism without Borders: Somalia's Al-Shabaab and the global jihad network
}

\section{by Daniel E. Agbiboa}

\section{(cc) $\mathrm{EY}$}

This work is licensed under a Creative Commons Attribution 3.0 License.

\section{Abstract}

This article sets out to explore the evolution, operational strategy and transnational dimensions of Harakat Al-Shabab al-Mujahedeen (aka Al-Shabab), the Somali-based Islamist terrorist group. The article argues that Al-Shabab's latest Westgate attack in Kenya should be understood in the light of the group's deepening ties with Al-Qaeda and its global jihad, especially since 2009 when Al-Shabab formally pledged allegiance to Osama bin Laden's Al-Qaeda and welcomed the organisation's core members into its leadership.

Key words: Al-Shabab, Westgate Attack; Al-Qaeda; Global Jihad; Kenya; Somalia.

\section{Introduction}

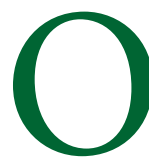

n 21 September 2013, the world watched with horror as a group of Islamist gunmen stormed Kenya's high-end Westgate Mall in Nairobi and fired at weekend shoppers, killing over 80 people. The gunmen reportedly shouted in Swahili that Muslims would be allowed to leave while all others were subjected to their bloodletting (Agbiboa, 2013a). Countries like France, Canada, the United States, the United Kingdom, Australia, New Zealand, and Ghana, among others, all confirmed that their citizens were among those affected. The renowned Ghanaian Poet, Kofi Awoonor, was also confirmed dead in the attack (Mamdani, 2013).

The Somali-based and Al-Qaeda-affiliated Islamist terrorist group, Harakat Al-Shabab al-Mujahideen or, more commonly, Al-Shabab - "the youth" in Arabic - have since claimed responsibility for the horrific attack through its Twitter account. In one tweet, the Islamist group said: “The Mujahideen entered \#Westgate Mall today at around noon and are still inside the mall, fighting the \#Kenyan Kuffar inside their own turf." In another tweet they stated their refusal to negotiate and later on said, "For long we have waged war against the Kenyans in our land, now its time to shift the battleground and take the war to their land" (Edmund and Richard, Reuters, September 21 2013; Agbiboa 2013b).

The above tweets suggest that Al-Shabab's Westgate attack was retribution for Kenya's military operations against the Islamist group in Somalia. Kenya has about 4,000 troops in southern Somalia. They intervened in 2011 following attacks and kidnappings in northern Kenya near the Somali border. The Kenyans were subsequently incorporated into a larger African Union (AU) force of 17,000 peacekeepers with a United Nations (UN) mandate to protect the weak Somali government. This mandate put the AU forces and AlShabab Islamists at daggers drawn (Onuoha, 2013).

This article sets out to explore the evolution, operational strategy and transnational dimensions of the Somali-based Islamist terrorist group, Al-Shabab. The article argues that Al-Shabab's latest Westgate attack 
should be understood in the light of the group's deepening ties with Al-Qaeda and its global jihad, especially since 2009 when Al-Shabab formally pledged allegiance to Osama bin Laden's Al-Qaeda and welcomed the organisation's core members into its leadership.

The article begins by exploring the evolution of Somalia's Al-Shabab, as well as its growing friendship with Al-Qaeda which has transformed the group into one that perpetrates the kind of coordinated attack we recently witnessed at the Westgate mall in Kenya. It then provides a brief explanation of the main objectives and unifying ideology of Al-Qaeda's global jihad, as well as expectations from Islamist groups, like Al-Shabab, that claim loyalty to the Al-Qaeda terrorist organisation. The conclusion summarises the key arguments of the article and outlines key knowledge requirements for more effective anti-terrorism measures.

\section{The Evolution and Transformation of Al-Shabab}

Al-Shabab was formed as a radical offshoot of the Islamic Courts Union (ICU), which, in 2006, controlled Mogadishu (Fergusson, 2013). The Islamist group, which controls about half of south-central Somalia, is estimated to have between 7,000 to 9,000 fighters, mainly recruited within Somalia but also from Western countries (BBC News Africa, 2013). Al-Shabab originally emerged as a remnant of al Itihaad al Islamiya (AIAI) - a Wahhabi Islamist terrorist organisation which arose in Somalia in the 1980s with the intention of replacing the regime of Mohammed Said Barre with an Islamic state. In 2000, AIAI remnants - mostly young members - reformed into Al-Shabab and were incorporated into the ICU as its radical youth militia.

The Ethiopian invasion [1] of Somalia in December 2006 marked a watershed in the development and radicalisation of Al-Shabab. First, it provided Al-Shabab with the opportunity to draw on deep-seated Somali hostility towards Ethiopia to recruit thousands of nationalist volunteers (Wise, 2011). Second, the invasion forced Al-Shabab to adopt an effective guerrilla-style operational strategy as a means of resisting Ethiopian advance into the South (Menkhaus and Boucek, 2010). Third, "by forcing the Islamic Courts Union leaders who had exerted a level of moderating influence on Al-Shabab to flee Somalia, the invasion allowed the group to become even more radical, while at the same time severing its ties to other Somali organisations" (Wise, 2011: 2). Although the Ethiopian invasion succeeded in routing the ICU and pushing Al-Shabab to the south of the country, it failed to end Islamic radicalism in Somalia; in fact, it was a primary factor in the ultra-radical turn of Al-Shabab, "transforming the group from a small, relatively unimportant part of a more moderate Islamic movement into the most powerful and radical armed faction in the country" (Wise, 2011: 4). In 2009 Ethiopia withdrew its troops from Somalia, replaced by the African Union Mission to Somalia (AMISOM) composed of thousands of Ugandan and Burundian peacekeeping forces.

Since 2008, Al-Shabab has demonstrated that it has the operational capability to launch deadly attacks against outposts of the West and perceived enemies outside Somalia. In October 2008, Al-Shabab coordinated five suicide bomb attacks that hit the UN Development Programme compound, the Ethiopian consulate and various government offices, killing several dozen (Ali Noor, 2008). In September 2009, Al-Shabab bombed the African Union peacekeeping mission in Mogadishu, killing more than 20 people and damaging the offices of a U.S. firm that was purportedly providing support to peacekeepers (Agbiboa, 2013b). In July 11, 2010, Al-Shabab claimed responsibility for suicide bombing of two groups of fans watching the World Cup in the Ugandan capital, Kampala, which killed more than 70 people, including one American citizen. The Ugandan attacks, according to Al-Shabab, were launched to punish the country for its role in assisting AMISOM forces in Somalia (Onuoha, 2013), in the same way that the recent Westgate attack was launched to punish Kenya for its military operations in Somalia since August 2011. 


\section{Journal of Terrorism Research}

The argument that I make in this article is that to understand the transformation of Al-Shabab, one has to consider how the group came to be incorporated within a global jihadist movement led by Al-Qaeda.

\section{Forging ties between Al-Qaeda and Al-Shabab}

Al-Qaeda operated in Sudan in the early 1990s as host of the Islamist regimes of Omar al Bashir and Hassan al Turabi (Lorenzo et al. 2010: 218). However, the organisation soon set its sights on war-torn Somalia when it learnt that American troops were going to be deployed into it in order to restore order and provide supplies to the local population. Addressing a core group of Al-Qaeda members in late 1993, Bin Laden declared: "The American army now they came [sic] to the Horn of Africa, and we have to stop the head of the snake... the snake is America, and we have to stop them. We have to cut the head and stop them" (cited in Lorenzo et al. 2010: 218). Following discussions between Al-Qaeda's military wing commander Abu Hafs al Masri and AIAI's military wing commander Shaykh Hassan Awey's, four Al-Qaeda instructors were sent to Somalia to "train other Somalis" linked to the AIAI in advanced combat tactics and weapons. According to the AlShabab Media Foundation, Al-Qaeda's official propaganda wing, these instructors taught Somali Islamists "the tactics of guerrilla warfare, in addition to taking part in a number of combat operations against the Americans" (Lorenzo et al. 2010: 218).

The relationship between Al-Qaeda and the AIAI leadership continued after the US withdrew from Somalia. In 1996, Al-Qaeda moved its base to the Taliban-controlled Afghanistan, where Bin Laden forged a close relationship with the Taliban (CNN, February 5, 2002). A number of key members of the AIAI leadership travelled with Al-Qaeda to Afghanistan to receive training in Al-Qaeda's combat strategy, including suicide attacks and simultaneous bombings of different targets. One of them was Aden Hashi Farah Ayrow, a senior AIAI military commander. Propaganda materials released by Al-Shabab suggest that Ayrow grew "fond of the way Al-Qaeda worked and admired its doctrine, its strategy to change the Islamic world, and its call for jihad against Christians. Ayrow met many mujahedeen brothers in various positions within the organisation, and he also met Shaykh Usama Bin Laden, may Allah preserve him" (Lorenzo et al. 2010: 219). The report further noted that at the end of this first tour of Afghanistan, Ayro had become "a military encyclopaedia - he was unparallel in the Horn of Africa region... He took Shaykh Usama's advice and returned to Somalia in order to spread the idea of global jihad and the path of Al-Qaeda - confronting the Christian world" (Ibid). Starting in late 2001 the US war on terror in Afghanistan dispersed the organisation and forced it underground as its personnel were attacked and its bases and training camps destroyed (Hoffman, 2006).

Since 2009, Al-Shabab's deepening ties with Al-Qaeda has had profound effects on its structure and operational strategy. First, Al-Shabab's affiliation with Al-Qaeda significantly altered its leadership component. After the death of its leader, Aden Hashi Ayro, in May 2008, Al-Shabab's command structure welcomed a number of Al-Qaeda core members into top leadership roles (Roggio, 2010). Second, until 2008, Al-Shabab made use of relatively conventional guerrilla tactics in its attacks against the invading Ethiopian forces. However, the group's increasing ties with Al-Qaeda has led it down the path of suicide attacks as a means of achieving its ends. Reflecting a shift largely driven by its growing friendship with Al-Qaeda, AlShabab has emphasized the development of training camps for suicide bombers across Somalia and beyond (Wise, 2011). In fact, Al-Shabab has been linked to the training of Nigeria's Islamist terrorist group Boko Haram - "Western education is unlawful" in Hausa - which has killed over 10,000 people since its founding in 2002 (Agbiboa, 2013c, 2013d). In August 2011, General Carter Ham, Commander of the US Africa Command (AFRICOM) claimed that Boko Haram is financially sponsored by Al-Qaeda and Al-Shabab. He also alleged that both jihadist groups shared training and fighters with Boko Haram. He described that as 


\section{Journal of Terrorism Research}

"the most dangerous thing to happen not only to the Africans, but to us as well" (International Institute for Strategic Studies [IISS], 2011: 3).

It is instructive to note that the growth of information and communication technology (ICT) has enhanced the recent transformation of Al-Shabab, enabling the group not only to stay in contact with the extended jihadist family, but also attract and recruit foreign fighters (Saltman, 2008; Agbiboa, 2013b). ICT has also allowed Al-Shabab to tap into wealthy Salafi networks keen on supporting Al-Qaeda's global jihad campaign. In August 2009, Al-Shabab launched an online fundraising forum that raised 40,000 USD from members of the Somali Diaspora for the transnational jihadist cause (UN Monitoring Group on Somalia, 2010).

\section{Understanding the Transnational Jihadism of Al-Qaeda}

Al-Shabab's recent Westgate attack in Kenya should be understood in the light of the global jihadist campaign of the Al-Qaeda terrorist organisation-"a rather loose association of radical Salafist Islamist groups operating in many countries around the world that revere foundational members such as Saudi-born Osama Bin Laden, Egyptian-born Ayman al-Zawahiri, and the late Jordanian/Palestinian figure Abdullah Azzam and led by a transnational coterie of veterans of Islamist struggles around the world" (Piazza, 2009: 66). The organisation initially emerged from a network of Arab volunteers who, in the 1980s, fought in Afghanistan under the banner of Islam against Soviet Communism (BBC News, 20 July, 2004). The name "Al-Qaeda" itself etymologically derives from an Arabic word for "foundation" or "basis." Bin Laden explained the origin of the term in a videotape interview with Al Jazeera in October 2001: “The name 'Al-Qaeda' was established long time ago by mere chance. The late Abu Ebeida El-Banashiri established the training camps for our mujahedeen against Russia's terrorism. We used to call the training camp Al-Qaeda. The name stayed" (CNN, February 5, 2002).

Al-Qaeda's agenda is ideological, religious and political in nature, including (a) "unifying the Islamic world under a puritanical interpretation of Sunni Islam," (b) "the rejection of both secular rule and the institution of the nation-state in the Muslim world leading to the overthrow of all existing Muslim countries and the integration of all Muslim societies into a Caliphate," and (c) "the liberation of Muslim territories from foreign occupation, and the use of holy war (lesser jihad) to bind Muslims together and lead them through a 'clash of civilization' that will rid the Muslim world of non-Muslim cultural and political influence" (Piazza, 2009: 66).

Ina bid to build a coherent ideology (manhaj) that will unify all Islamists terrorist groups, Al-Qaeda leaders drew from takfiri thoughts, which justifies attacking corrupt governments in Muslim lands, and draws on materials that not only stress the need for militant groups to amalgamate, but also outline the Muslim requirement to target the global enemy (typically the US and the West). Subsequently, "the hybrid ideology that emerged makes little distinction between targeting local enemies and targeting global ones and have a one-size-fits-all solution-jihad" (Farall, 2011: 132). In other words, Al-Qaeda subsidiaries like Al-Shabab are only required to expand their focus, not abandon their own local agenda. The development of a coherent ideology helped Al-Qaeda acquire franchises which are crucial for projecting the organisation's power and gaining traction for its cause.

\section{Al-Qaeda Franchises}

The Al-Qaeda organisation founded a regional branch in the Arabian Peninsula (AQAP) and acquired franchises in Iraq (AQI) and the Maghreb (AQIM), reinforcing the organisation's ability to present itself as the leading Islamist militant group. Even as they pursued local agendas, the franchises were required to 


\section{Journal of Terrorism Research}

undertake some attacks against Western interests, and leaders of groups like Al-Shabab joining Al-Qaeda had to be willing to "present a united front, stay on message, and be seen to fall under Al-Qaeda's authority" (Farall, 2011: 132). Not surprising, Al-Qaeda-affiliated groups have all attacked Western interests in their respective regions.

AQAP has been looking to expand its terrorist attacks beyond Yemen and Saudi Arabia, as demonstrated by the botched attempt to explode a bomb on a flight over Detroit on Christmas Day 2009 and, in October 2010, the abortive plot to bomb cargo plane. AQI was allegedly involved in London and Glasgow bomb plots that occurred in June 2007. In Pakistan, the Taliban has extended its attack targets beyond Pakistan's borders to include Europe and the United States. The 2008 Mumbai attacks was clear evidence that Al-Qaeda's idea of attacking Islam's global enemies has found a fertile ground among Pakistan's Islamist militant groups like Lashkar-e-Taiba, which in the past focused only on Indian targets (Bergen et al. 2011: 74). In 2010, Nigeria's Boko Haram launched a suicide car bombing of the UN building in the capital, Abuja (Agbiboa, 2013e). Following the attack, Boko Haram released a statement that read: "All over the world, the UN is a global partner in the oppression of believers. We are at war against infidels. In Nigeria, the Federal Government tries to perpetuate the agenda of the United Nations... We have told everyone that the UN is the bastion of the global oppression of Muslims all over the world" (The Punch, September 2, 2011).

To what degree does Al-Qaeda exercise command and control over its dispersed structure and subsidiaries like Al-Shabab? Al-Qaeda is not a hierarchical organisation with full control over its franchises. Rather, the organisation operates as "a devolved network hierarchy in which levels of command authority are not always clear; personal ties between militants carry weight, and at times, transcend the command structure between core, branch and franchises" (Farall, 2011: 133). Due to the already existing unifying ideology, Al-Qaeda need only provide "strategic leadership" rather than "day-to-day oversight" (Ibid). Nevertheless, before launching any attack, all Al-Qaeda-affiliated groups are required to seek approval from the central Al-Qaeda leadership. The aim is to ensure that attacks, like the Westgate attack, reinforce, not undermine, Al-Qaeda's strategic objectives (Agbiboa, 2013c).

\section{Conclusion}

This article has explored the evolution and transformation of Somalia's Al-Shabab. The article argued that Al-Shabab's latest Westgate attack should be understood in the light of the group's deepening ties with Al-Qaeda which has radically altered the group's ideology and operational strategy. Clearly, Al-Shabab's continued terrorist activity is not detached from that of other jihadist groups in Africa - including Boko Haram, Ansaru, and Al-Qaeda's North African wing - and beyond. It should be recalled that in 2012 the US military officials warned that these jihadist outfits were increasingly joining forces to coordinate and make more sophisticated their violent attacks. Military crackdowns on these groups in recent years - the Nigerian military on Boko Haram; the French attack on Al-Qaeda affiliates in Mali; the Ethiopian and AU routing of Al-Shabab from Somalia - have been incendiary and counterproductive, failing to stamp out Islamist terrorism.

Processes of globalisation have facilitated the spread of terrorism that extends across and beyond national borders - as the recent Westgate attack demonstrates - blurring the distinction between domestic and transnational terrorism. This holds at least two significant implications for how we think about and prepare responses to terrorist groups like Al-Shabab. One implication is the urgent need to better understand their power, command and control relationships with the global jihad network. Another implication is the need for countries fighting terror, like Somalia, to be assisted in strengthening their intelligence and civilian 


\section{Journal of Terrorism Research}

institutions, promoting the rule of law, and addressing the underlying existential and ideological conditions that radicalises Islamist groups and fuel terrorism without borders.

About the author: Daniel E. Agbiboa is a DPhil Candidate and holder of the prestigious Queen Elizabeth House (QEH) Doctoral Scholarship in the Oxford Department of International Development, University of Oxford, UK. He holds an MPhil in Development Studies from the University of Cambridge, an MA in International Relations from the University of KwaZulu-Natal, and an Advanced Certificate in Social Research from the Australian National University. His research interests are in the field of corruption, regional security and development, with a sub-regional focus on West and East Africa. He has over 35 publications in peer-reviewed journals, including Third World Quarterly, African Security Review, and Conflict, Security and Development. daniel. agbiboa@qeh.ox.ac.uk

\section{Notes}

[1] Ethiopia shares a long history of animosity with Somalia.

\section{Bibliography}

Agbiboa, D.E. (2013a). "Peace at Daggers Drawn: Boko Haram and the State of Emergency in Nigeria." Studies in Conflict and Terrorism, 37 (1): 41-67.

Agbiboa, D.E. (2013b). “Al-Shabab's Dangerous Affair with Al-Qaeda.” Journal of Social, Political and Economic Studies, 38(4): 425-440.

Agbiboa, D.E. (2013c). "Why Boko Haram Exists: The Relative Deprivation Perspective." African Conflict and Peace-building Review 3 (1), p. 147.

Agbiboa, D.E. (2013d). "Al-Shabab, the Global Jihad, and Terrorism without Borders." Aljazeera, September 24. Available at: http://www.aljazeera.com/indepth/opinion/2013/09/Al-Shabab-global-jihadterroris-201392484238627603.html. (Accessed 26 September 2013).

Agbiboa, D.E. (2013e). "No Retreat, No Surrender: Understanding the Religious Terrorism of Boko Haram." African Study Monograph, 34(2): 65-84.

Ali Noor, H. “Suicide Bombers Kill at least 28 in Somalia." Reuters, October 29.

Asal, Victor and Blum, Andrew. (2005). "Holy Terror and Mass Killings? Re-examining the Motivations and Methods of Mass Casualty Terrorists." International Studies Review 7(1), pp. 153-155.

BBC News. (2013). “Q\&A: Who Are Somalia's Al-Shabab?” September 23. Available at: http://www.bbc. co.uk/news/world-africa-15336689 (Accessed 26 September 2013).

Bergen, Peter, Hoffman, Bruce and Tiedemann, Katherine. (2011). "Assessing the Jihadist Terrorist Threat to American Interests." Studies in Conflict and Terrorism 34 (2), p. 74.

Blair, Edmund and Lough, Richard. (2013). “Islamists claim Gun Attack on Nairobi Mall.” Reuters, September 21. Available at: http://www.reuters.com/article/2013/09/21/us-kenya-attack-idUSBRE98K03V20130921 (Accessed 25 September 2013).

Farrall, L. (2011). "How Al-Qaeda Works: What the Organisations Subsidiaries say about its Strength." Foreign Affairs 90 (2), p. 132.

CNN (2013. 'Transcript of Bin Laden's October Interview.' February 5. http://edition.cnn.com/2002/WORLD/ 


\section{Journal of Terrorism Research}

asiapcf/south/02/05/binladen.transcript/ (Accessed 6 December 2013).

Fergusson, J. (2013). The World's Most Dangerous Place: Inside the Outlaw State of Somalia. De Capo Press; Bantam.

Hansen, S.J. (2013). Al-Shabab in Somalia: The History and Ideology of a Militant Islamist Group, 2005-2012. Oxford: Oxford University Press.

Hoffman, B. (2006). Inside Terrorism. Columbia: Columbia University Press.

International Institute for Strategic Studies (IISS). (2011). "Boko Haram: Nigeria’s Growing New Headache." Strategic Comments 17 (9), p. 3.

Lorenzo, V., Pantucci, R. \& Kohlmann, E. (2010). 'Bringing Global Jihad to the Horn of Africa: Al-Shabab, Western Fighters, and the Sacralization of the Somali Conflict.' African Security 3(4): 216-238.

Mamdani, M. (2013). "Senseless and [Sensible] Violence: Mourning the Dead at Westgate Mall." Aljazeera, September 26. Available at http://www.aljazeera.com/indepth/opinion/2013/09/senseless-sensible-violencemourning-dead-at-westgate-mall-201392563253438882.html (Accessed 27 September 2013).

Menkhaus, K. and Boucek, C. (2010). “Terrorism out of Somalia.” Carnegie Endowment for International Peace, September 23. Available at http://carnegieendowment.org/2010/09/23/terrorism-out-of-somalia/wnc (Accessed 15 November 2013).

Onuoha, F. (2013). “Westgate Attack: Al-Shabab’s Renewed Transnational Jihadism.” Al-Jazeera Center for Studies, November 10. Available at http://studies.aljazeera.net/ResourceGallery/media/ Documents/2013/11/11/20131111123040955734Kenya.pdf (Accessed 15 November 2013).

Piazza A. James. (2009). "Is Islamist Terrorism More Dangerous? An Empirical Study of Group Ideology, Organization, and Goal Structure." Terrorism and Political Violence 21 (1), p. 64.

Roggio, B. (2010). “Al-Qaeda Leaders play significant role in Shabaab," Long War Journal, August 1. http:// www.longwarjournal.org/archives/2010/08/al qaeda leaders pla.php. (Accessed 16 August 2013).

Roggio, B. (2013). “Nigerian Jihadist Group Executes 7 Foreigners.” The Long War Journal, March 9. Available at: http://www.longwarjournal.org/archives/2013/03/nigerian jihadist gr.php. (Accessed 12 September 2013).

Saltman, S. (2008). “The Global Jihad Network: Why and How Al-Qaeda Uses Computer Technology to Wage Jihad." Journal of Global Change and Governance, 1(3). Available at http://www.acsa.net/TW/samples/ saltman.pdf. (Accessed 18 September 2013).

The Punch (Nigeria). (2011). "Boko Haram Names UN Suicide Bomber." September 2. Available at: http:// www.punchng.com/Articl.aspx?theartic=Art201109025394160. (Accessed 18 September 2013).

Umar, S. (2011). The Discourses of Salafi Radicalism and Salafi Counter-Radicalism in Nigeria: A Case-Study of Boko Haram. Evanston, IL: Northwestern University Press.

United Nations Monitoring Group on Somalia (2010). Report of the Monitoring Group on Somalia Pursuant to Security Council Resolution 1853(2008). March 10. Available at http://www.un.org/ga/search/view doc/ asp?symbol=s/2010/91. (Accessed 16 June 2013).

Wise, R. (2011). “Al-Shabab.” Case Study Number 2, Center for Strategic and International Studies, Washington, DC.

Zenn, J. (2013). “Cooperation or Competition: Boko Haram and Ansaru after the Mali Intervention.” March 
The Centre for the Study of Terrorism and Political Violence

\section{Journal of Terrorism Research}

27. Available at: http://www.ctc.usma.edu/posts/cooperation-or-competition-boko-haram-and-ansaru-afterthe-mali-intervention. (Accessed 16 August 2013). 